\title{
The first unified inventory of non-native fishes of the South Caucasian countries, Armenia, Azerbaijan, and Georgia
}

\author{
Tatia Kuljanishvili1,* (D), Levan Mumladze ${ }^{2}$ (D), Bella Japoshvili ${ }^{2}$ (D), Namig Mustafayev ${ }^{3}$ (D), \\ Shaig Ibrahimov ${ }^{3}$, Jiří Patoka ${ }^{1}$ (1), Samvel Pipoyan ${ }^{4}$ (1) and Lukáš Kalous ${ }^{1, *}$ \\ ${ }^{1}$ Department of Zoology and Fisheries, Faculty of Agrobiology, Food and Natural Resources, Czech University of Life Sciences Prague, \\ Kamýcká 129, Praha 6 - Suchdol, 16500 Czech Republic \\ ${ }^{2}$ Institute of Zoology, Ilia State University, Cholokashvili ave. 3/5, Tbilisi 0162, Georgia \\ ${ }^{3}$ Institute of Zoology, National Academy of Sciences of Azerbaijan, Hüseyn Cavid Prospekti, Bak1, Baku, Azerbaijan \\ ${ }^{4}$ Armenian State Pedagogical University after Kh. Abovyan, Tigran Mets 17, Yerevan 0010, Armenia
}

Received: 14 June 2021 / Accepted: 17 July 2021

\begin{abstract}
The South Caucasus (SC) region is recognized for its high biological diversity and various endemic animal taxa. The area has experienced many fish introductions over the years, but the overall information about non-native fishes in the three SC countries, Armenia, Azerbaijan, and Georgia did not exist. Although these three countries belong to the Kura River drainage, Caspian Sea basin (only the western half of Georgia drains into the Black Sea), the legislative framework for each country regarding introduction of non-native fish species and their treatment is different and poorly developed. The goal of the present study was to make an initial inventory of non-native fish species in the three SC countries, and summarize the existing knowledge as a basis for future risk assessment models and formulation of regional management policies. Here, we present a unified list of 27 non-native species recorded in the wild in Armenia, Azerbaijan, and Georgia. Among these 27 species, eight were translocated from the Black Sea basin to the Caspian Sea basin. Out of these 27 non-native fishes, 15 species have become established (three of them being considered invasive) and six fish species could not survive in the wild.
\end{abstract}

Keywords: Introduction / invasive species / translocated species / aquaculture / recreational fisheries

Résumé - Le premier inventaire commun des poissons non indigènes des pays du Caucase du Sud, Arménie, Azerbaïdjan et Géorgie. La région du Caucase du Sud (SC) est reconnue pour sa grande diversité biologique et ses divers taxons animaux endémiques. La région a connu de nombreuses introductions de poissons au fil des ans, mais il n'existait pas d'informations générales sur les poissons non indigènes dans les trois pays du SC, l'Arménie, l'Azerbaïdjan et la Géorgie. Bien que ces trois pays appartiennent au bassin versant de la rivière Kura, dans le bassin de la mer Caspienne (seule la moitié occidentale de la Géorgie se déverse dans la mer Noire), le cadre législatif de chaque pays concernant l'introduction d'espèces de poissons non indigènes et leur traitement est différent et peu développé. L'objectif de la présente étude était de dresser un premier inventaire des espèces de poissons non indigènes dans les trois pays du SC, et de résumer les connaissances existantes afin de servir de base aux futurs modèles d'évaluation des risques et à la formulation de politiques de gestion régionales. Nous présentons ici une liste unifiée de 27 espèces non indigènes enregistrées à l'état sauvage en Arménie, en Azerbaïdjan et en Géorgie. Parmi ces 27 espèces, huit ont été transférées du bassin de la mer Noire au bassin de la mer Caspienne. Sur ces 27 poissons non indigènes, 15 espèces se sont établies (trois d'entre elles étant considérées comme invasives) et six espèces de poissons n'ont pas pu survivre à l'état sauvage.

Mots clés : Introduction / espèces invasives / espèces déplacées / aquaculture / pêche récréative

\section{Introduction}

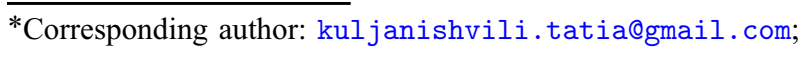

kalous@af.czu.cz
Non-native (alien) species are of great concern for their potential effects on biological diversity (Vitousek et al., 1996; 
Jeschke et al., 2014). Aquatic alien species can be introduced intentionally, through aquaculture, recreational fisheries, or ornamental trade; or unintentionally, through ballast water transport, as a contaminant of parcels, or accidental escapes from captivity. Less frequently, species can also invade new areas without human involvement (Copp et al., 2005 and citations herein). Non-native invasive species can cause significant negative impacts on native fauna, and cause socio-economic losses to affected regions (Ricciardi, 2003; Gallardo and Aldridge, 2013). For this reason, it is worthwhile to invest in the prevention of introductions and if a species is introduced, develop plans for functional management of the invasive alien species. In this regard, one of the vital steps is to scrutinize the alien species lists for a particular region of interest to identify, assess, monitor, and mitigate non-native species in a timely manner. Most countries in Europe and overseas have developed such lists and most importantly, this information has subsequently been used in drafting more effective legislations (Manchester and Bullock, 2000; Copp et al., 2005; Povž and Šumer, 2005; Koščo et al., 2010; Mastitsky et al., 2010; Musil et al., 2010; Lenhardt et al., 2011; Ribeiro and Leunda, 2012; Simonović et al., 2013; Piria et al., 2017). However, there are still some countries that do not maintain lists of invasive species introductions or have developed strategies for managing non-native species and these include the South Caucasian (SC) countries, Armenia, Azerbaijan, and Georgia.

Situated at the junction of Europe and Asia as the land between the Black and Caspian seas, the SC region encompasses a total area of $186,000 \mathrm{~km}^{2}$ and has an incredibly variable landscape and climate. It is characterized by wide species diversity and a high level of endemism. Due to these and other reasons, the region has been recognized as one of the world's biodiversity hotspots (Myers et al., 2000). According to aquatic biodiversity, the SC can be divided into the basins of the Black and Caspian Seas. However, based on its complex geological and paleo-ecological history, coupled with characteristic aquatic assemblages, finer scale biogeographical subdivisions have also been proposed (Abell et al., 2008; Naseka, 2010). On a wider biogeographical scale, the SC belongs to the Ponto-Caspian region which is one of the primary sources of aquatic invaders worldwide, causing huge economic losses and biodiversity impacts (Bij de Vaate et al., 2002). Unsurprisingly, the SC region is also a recipient of alien non-native aquatic species. However, the changes in diversity, the invasion trends, and the socio-economic impact of non-native aquatic species in the SC ecosystems are still poorly understood (Japoshvili et al., 2020). For instance, the diversity, distribution, and the effect of non-native fish species on autochthonous biota and the local economy in the SC have never been the subject of a research study. Even a basic list of non-native fish species does not exist for the entire region or any country within it. According to a recent checklist of fishes (Kuljanishvili et al., 2020), 119 freshwater fish species are currently recognized in the region with many relics and endemic species, and several introduced (established) species. However, these only included established non-native species and no other introduced non-native species such as, for instance, Chinese carps of the genera Ctenopharyngodon and Hypophthalmichthys have been discussed. Thus, in-depth understanding of the relationship between native and non-native fish fauna of the SC countries cannot be obtained.

The overarching goal of the present research was to produce a unified, mainly literature-based inventory of the non-native fish species of Armenia, Azerbaijan, and Georgia, and to summarize the existing knowledge base for creating risk assessment models and drafting region-scale management policies. Firstly, we aimed to comprehensively review the national legislative framework and policies to identify trends and gaps in non-native fish species management in SC countries. Secondly, we attempted to prepare an annotated list of non-native fish species agreed upon by fish experts for SC countries. Lastly, we sought to identify the donor areas and pathways for fish introductions and evaluate the establishment success for each non-native fish species.

\section{Materials and methods}

\subsection{Study area}

The SC and its three countries, Armenia, Azerbaijan, and Georgia (around $5 \%$ of the area of eastern Azerbaijan and northern Georgia belongs to the Northern Caucasus) is encompassed between the Black and Caspian seas. Only the western half of Georgia drains into the Black Sea and accordingly most of the SC represents the Caspian Sea basin (Fig. 1).

Among the SC countries, only Armenia is landlocked with an area of about $30,000 \mathrm{~km}^{2}$ inhabited by approximately 3 million people. Most of Armenia is situated in the highlands of the Lesser Caucasus and belongs to either the Aras River basin, which is a tributary of the Kura River, or the closed basin of the largest lake in SC, Sevan Lake, with a surface area of $1,250 \mathrm{~km}^{2}$ and its own river system (Central Intelligence Agency, 2020). Azerbaijan lies on the easternmost southern slope of the Greater Caucasus bordering the Caspian Sea on the east. The country covers almost $83,000 \mathrm{~km}^{2}$ and is inhabited by approximately 10 million people. Most of the country is formed by the Kura-Aras lowland and the Karabakh upland (Central Intelligence Agency, 2020). In addition to the Kura River, there are numerous small streams directly flowing into the Caspian Sea. Georgia is located mostly along the southern slope of the Greater Caucasus bordering the Black Sea on the west and the Lesser Caucasus Mountains in the south of the country. Georgia covers a terrestrial area of almost $70,000 \mathrm{~km}^{2}$ and is inhabited by approximately 4 million people (Central Intelligence Agency, 2020). The landscape is largely mountainous with the Colchis lowland on the west and the lowland between the Kura and Alasani Rivers in the east. The territory of Georgia is divided into the Black Sea and the Caspian Sea basins, and thus is the only SC country that includes both sea basins.

\subsection{Legislative framework}

To review and compare the legislative regulations for aquaculture, introduction and stocking of non-native fishes, and recreational fisheries, the laws and subordinate documents were obtained from the Ministry of Environment of the Republic of Armenia (MERA), the Ministry of Ecology and 


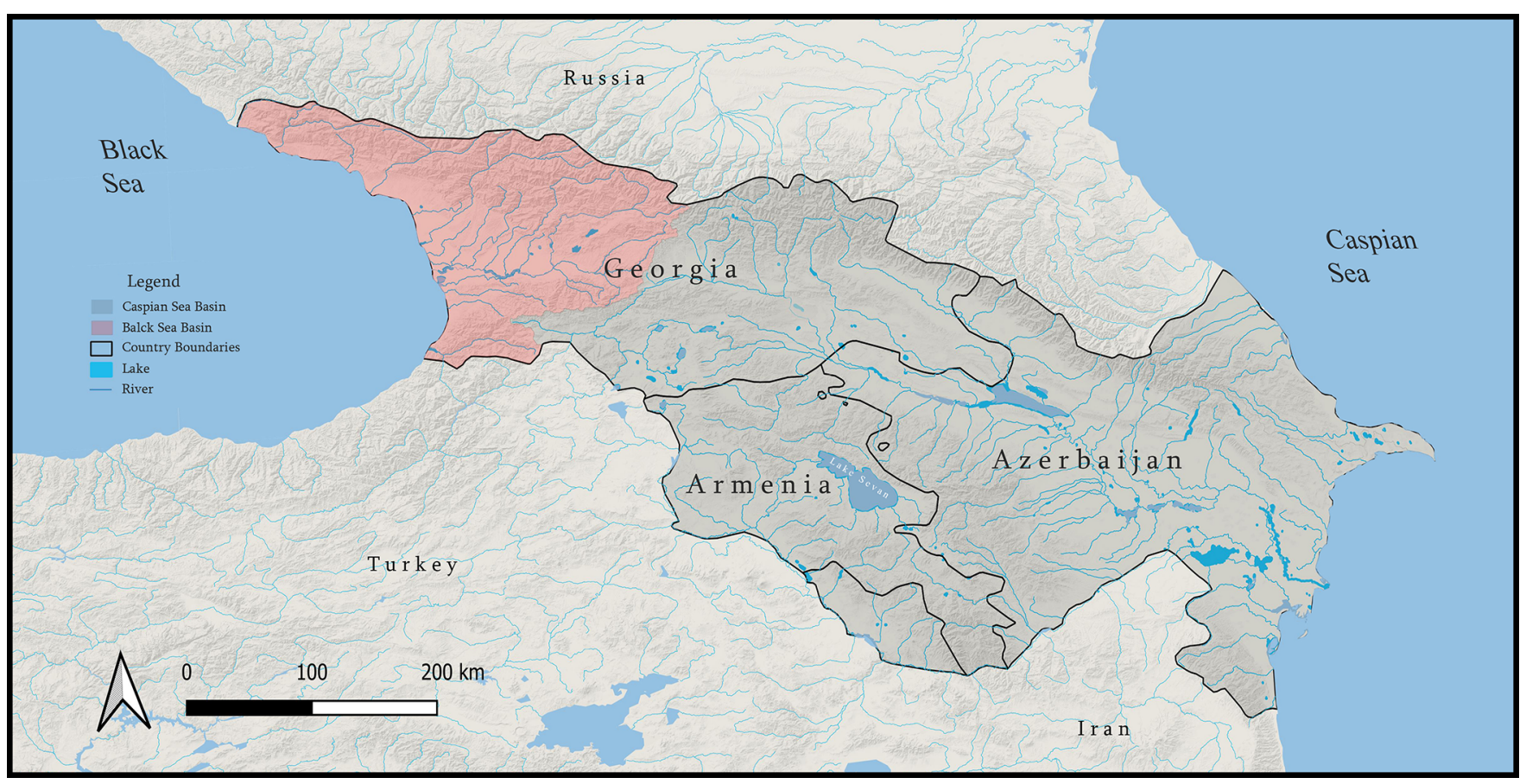

Fig. 1. The map of freshwaters of South Caucasian countries: Armenia, Azerbaijan, and Georgia.

Natural Resources of the Azerbaijan Republic (MENRAR), the Ministry of Emergency Situations of the Azerbaijan Republic (MESAR), and the Ministry of Environmental Protection and Agriculture of Georgia (MEPAG). Particular attention was given to the following topics: (1) regulation of fish stocking in rivers, lakes and reservoirs, (2) definition and representation of non-native fish species in the legislative framework, (3) treatment of non-native fish species in aquaculture, to see if there is different treatment for native and non-native fish species in aquaculture farming, (4) regulations about the introduction of non-native fish species, (5) regulations on stocking non-native fish species in rivers, lakes and reservoirs, and (6) regulations on recreational fisheries.

\subsection{The list of non-native species}

Under the term non-native fish, we included species that were introduced from outside the SC, and translocated species, those native to a part of the $\mathrm{SC}$ region that were introduced to a new part of the region where they did not occur before (mainly species translocated from the Black to the Caspian basin). Due to ethnocultural heterogeneity in the region, the exchange of information is complicated and often delayed. Most of the information is only available in the local languages of Armenian, Azeri, or Georgian, or in Russian, which makes it impossible to access or even search for a wider international community. For that reason, we collated and synthesized information on non-native fish species within the SC countries based on all available sources, including scientific and 'grey' (both recent and old) publications, reports, and selfobservations.

The non-native species list includes all the non-native and translocated species that have been recorded in the wild in the study area. In addition, the list includes the species that do not exist anymore. Each species in the list is discussed separately with the notes. These notes were arranged in five topics including (1) the origin and native range, (2) donor areas, the place the species was introduced from, (3) the chronology of species introduction events showing in which decades the most introductions happened (for species lacking a documented introduction date, the years of first introductions were recorded as decades after reviewing their first mention in the scientific literature), (4) pathways of introductions, and (5) establishment status of non-native fish species, showing whether the species have created self-sustainable populations in new areas and discussion of the potential risk of invasion and their effect on biodiversity, ecosystems and socio-economic conditions. Species invasiveness was evaluated according to a literature review of the records of the species invasiveness in countries with similar climate conditions, and self-observations. The last section provided individual summaries and discussions about the donor areas, decades of introduction, and pathways of introduction, and establishment state of non-native species.

\section{Results and discussion}

\subsection{The legislative framework}

Armenia, Azerbaijan, and Georgia are currently classified as developing countries (https://www.worldbank.org/) that started their independent destinies in 1991 after the dissolution of the Soviet Union. During the Soviet era, there was the centralized Soviet legislative body regulating the fifteen republics united within the Soviet Union. However, after dissolution, the independent states including the SC countries started developing their own legal frameworks, but with little solid experience. A constitution as the main format for the legal system was adopted in 1995 by all three SC countries, and 
T. Kuljanishvili et al.: Knowl. Manag. Aquat. Ecosyst. 2021, 422, 32

Table 1. The list of legislatives concerning the regulation of aquaculture/fish stocking, introduction of non-native species, stocking of nonnative species, and recreational fisheries in Armenia, Azerbaijan, and Georgia.

\begin{tabular}{lllll}
\hline & Aquaculture/fish stocking & $\begin{array}{l}\text { Introductions } \\
\text { of non-natives }\end{array}$ & $\begin{array}{l}\text { Stocking } \\
\text { of non-natives }\end{array}$ & Recreational fisheries \\
\hline Armenia & $2007^{1} ; 2002(a)^{2} ; 2009(a)^{3} ; 2019(a)^{4}$ & $2002(b)^{5}$ & - & $2003^{6} ; 2009(b)^{7} ; 2009(\mathrm{c})^{8} ; 2019(\mathrm{~b})^{9} ; 2020^{10}$ \\
Azerbaijan & $2017^{11}$ & $1998^{12}$ & $2017^{11}$ & $2017^{11}$ \\
Georgia & $2005^{13} ; 2021^{14}$ & $1996^{15}$ & $2021^{14}$ & $2013^{16}$ \\
\hline
\end{tabular}

${ }^{1}$ The Republic of Armenia Law No. 176 of 2007 "On Hunting and Maintaining Hunting Economy".

${ }^{2}$ The Republic of Armenia Government Decision No. 1380-N of 22.08.2002(a) "On Approving the Regulation of Concluding Contracts on the Use of Fauna Objects for Agricultural and Industrial Purposes in the Republic of Armenia".

${ }^{3}$ The Republic of Armenia Government Decision No. 975-N of 13.08.2009(a) "On Approving the State Registration Program of the Republic of Armenia Fauna".

${ }^{4}$ Order of the Republic of Armenia Minister of Nature Protection of 12.02.2019(a) "On Approving Contracts and Applications on the Use of Wild Animals (Amateur Hunting and Fishing, Animal Hunting That are not Objects of Fishing or Hunting) for Social Purposes in the Republic of Armenia".

${ }^{5}$ The Republic of Armenia Government Decision No. 1174-N of 18.07.2002(b) "On the Regulation of the Export of Wild Animals, Zoological Collections and Individual Samples from the Territory of the Republic of Armenia and Their Import into the Territory of the Republic of Armenia".

${ }^{6}$ The Republic of Armenia Government Decision No. 884-N of 10.07.2003 "On Approving the Regulation of Concluding Contracts on the Use of Fauna Objects for Social Purposes".

${ }^{7}$ The Republic of Armenia Government Decision No. 121-N of 22.01.2009(b) “On Approving the Regulation of Organizing and Implementing the Fauna Monitoring".

${ }^{8}$ Order of the Minister of Nature Protection of the Republic of Armenia No. 9-N of 15.02 2009(c) "On Approving Hunting Rules".

${ }^{9}$ The Republic of Armenia Government Decision No. 1667-N of 21.11.2019(b) “On Approving the Regulation of the Restoration, Preservation and Reproduction of Fish and Crayfish Stocks in the Lake Sevan, as well as Their Stocks Definition, the Quantities, Forms and Organization of Fish and Crayfish Industrial Hunting".

${ }^{10}$ Order of the Minister of the Nature Protection of the Republic of Armenia No. 36-N of 3.02.2020 "On Defining the Permissible Quantities for Hunting (Amateur Fishing) for Social Purposes in the Water Areas of the Republic of Armenia During 2020".

${ }^{11}$ Decision of the Cabinet of Ministers of the Republic of Azerbaijan No. 243 of 2.06.2017 "On the Rules for the Fishing and Extraction Other Aquatic Biological Resources".

${ }^{12}$ Law of the Azerbaijan Republic "On Fisheries" of 27.03.1998.

${ }^{13}$ Order of the Government of Georgia No. 138. of 11.09.2005 "On Approving of the Regulation on the Rules and Conditions for Issuing a Fishing Licenses".

${ }^{14}$ Law of Georgia on Aquaculture of 1.03.2021.

${ }^{15}$ Law of Georgia on Animal World of 26.12.1996.

${ }^{16}$ Order of the Government of Georgia No. 423 of 31.12.2013 "On Approving of the Technical Regalement on Fishing and Protection of Fish Stocks".

additional legislation has been passed over the years since then, although, not surprisingly, environmental, and biodiversity-related laws are not among the front-runners. For example, the regulation and management of the fisheries industry, as well as related environmental issues, was deregulated during the last decade of the 20th century. These regulations have been gradually reinstated over the past two decades but they are still being considered for development. For instance, the pet trade is one of the main routes for non-native species introductions (Magalhães and Vitule, 2013; Patoka et al., 2018), yet it still lacks an effective legislative framework in the three SC countries.

In Table 1, we summarized the legislation concerning regulation of the introduction and stocking of non-native species for aquaculture and recreational fisheries in Armenia, Azerbaijan, and Georgia. We reviewed ten current legislative acts related to aquaculture and fisheries in the SC countries and found that Armenia had no laws regulating the stocking of non-native fish species. Currently, there are only two relevant sets of regulations in Azerbaijan and four in Georgia (Tab. 1).

\subsubsection{Regulation of fish stocking in rivers, lakes, and reservoirs}

Fish stocking in the wild is allowed in Armenia and is carried out on a scientific basis with the consent of the MERA. In general, however, the government does not support fish stocking in rivers, lakes, and reservoirs unless really necessary. In Azerbaijan, fish stocking in natural water bodies is possible only upon obtaining a license from MENRAR and MESAR and allowing them to conduct scheduled monitoring of all natural reservoirs. As in Azerbaijan, stocking into natural water bodies in Georgia is possible after obtaining a license from the National Environmental Agency (NEA) of the MEPAG. The license can be obtained through an auction and is usually good for 20 years. The applicant for the license must present to the NEA a plan describing what kind of fish and in 
what quantities will be released. The license holder is obligated to present a five-year plan about the species composition and quantity in the water body as well as report monthly catches to the NEA. Although the regulations exist, the subsequent monitoring is poorly run. It is allowed to release non-native fish for stocking into state-owned water bodies in Armenia, Azerbaijan and Georgia though a license, but local anglers frequently release the fry of various non-native fishes into these water bodies intentionally without a license (unpublished information). This may explain the rapid spread of notoriously invasive fish such as the Prussian carp (Carassius gibelio) and stone moroko (Pseudorasbora parva).

\subsubsection{Definition and representation of non-native fish species in the legislative framework}

Although non-native fish species are managed by some laws, the definition of 'non-native' and a list of these species are not to be found in the legislation of Armenia and Azerbaijan. There is a definition of 'Introduction' in Georgian laws, as "introduction of species of alien fauna or flora for the purpose of releasing them into nature". However, the act does not provide a list of non-native fish species. In the National Biodiversity Strategy and Action Plan (NBSAP) of Georgia, approved in 2014, there was a national target (B2) aiming by 2020 to evaluate the diversity of invasive species in Georgia, the pathways of their introduction, and their effects on ecosystems (NBSAP, 2014). Unfortunately, the target was not prioritized, and no actions have been taken towards it. Currently, there is no catalogue of alien invasive species indicating which should be placed on a black-list banning them from introduction into the SC countries. Because of the lack of official guidelines for identifying non-native species, decisionmakers in SC countries are using the existing scientific literature (Pipoyan, 2012; Ninua et al., 2013; Ibrahimov and Mustafayev, 2015; Pipoyan et al., 2018) and their own knowledge as a rough guide.

\subsubsection{Treatment of non-native fish species in aquaculture}

Current Armenian legislation does not include any statements concerning non-native species in aquaculture. In Azerbaijan, some non-native fish species such as Ctenopharyngodon idella, Hypophthalmichthys molitrix and H. molitrix; Onchorhynchus sp. and Salmo gegarkuni are allowed as acclimatization objects in aquaculture and Chelon auratus and C. saliens are allowed for industrial fishing, provided that permission is obtained from MENRAR. According to the Law on the Animal World, introduction of non-native species in Georgia is forbidden. In practice, however, some exceptions are allowed for species used in aquaculture. For instance, according to the current laws on fishing and protection of fish stocks, the owner of a certain body of water can get a license for the introduction of non-native species such as Chinese carps for stocking in aquaculture since, these species have been introduced in the early 20th century (Barach, 1941; Elanidze, 1983) and thus they are considered as important acclimatized fisheries subjects and are included in books on Georgian fishes (Elanidze, 1983). To introduce a non-native species, license holders are only required to provide a relevant veterinary certificate (pers. comm., Partsvania, 2018; Mdivani, 2018).
Drafting guidelines for laws dealing with non-native fish for aquaculture should be a primary goal of each country's legislation. Although there are laws at least partly dealing with non-native species introductions in all three SC countries, they are ineffective. This is largely because of flaws in the understanding of the definition of non-native fish species and the possibility that non-native species may be viewed as something else entirely.

\subsubsection{Regulations about the introduction of non-native fish species}

Illegal imports of animals to the Republic of Armenia, relocation to another habitat, acclimatization, and use for selective purposes had been strictly forbidden. According to the former Armenian Law on Environmental Impact Assessment and Expertise, the process of importing non-native species into the territory of the Republic of Armenia was subject to environmental impact assessment by experts. However, that law was repealed in 2014 , so that currently there is no normative act restricting fish species introduction. Meanwhile, in Azerbaijan, the introduction of any non-native fish species for the purpose of production, restoration, protection, or acclimatization is legally possible by obtaining the permission of MENRAR. To stock fish in Georgia, the farmer must present a document to the NEA affirming that the introduced species will not affect native species, their habitats, or ecosystem in case it escapes into the wild. For example, this was the way the African catfish (Clarias gariepinus Burchell, 1822) was imported from European countries such as Poland, Netherlands, and Moldova, and was introduced and kept in specially established aquaculture facilities in Georgia. A similar situation applied to brook trout (Salvelinus fontinalis Mitchill, 1814) and arctic char (Salvelinus alpinus L., 1758), which were purchased as fertilized eggs from Canada and kept in a closed systems (pers. comm., Partsvania, 2018). From these examples, it can be seen that the introduction of non-native fish species is poorly regulated in SC countries. If the introduction of non-native species is essentially unrestricted according to Armenian laws, if non-native species are considered as acclimatized in Azerbaijani laws, and if non-native species such as Chinese carp introduced for aquaculture are not considered as non-natives in Georgia, it simply means that introductions of non-native fish species are allowed for all SC countries with no further limitations.

\subsubsection{Regulations on stocking non-native fish species in rivers, lakes and reservoirs}

There are no laws for the regulation of non-native fish stocks in Armenia except where resettlement and reproduction in natural conditions are concerned; then, it must be carried out with the consent of the MERA. In Azerbaijan, the process of introducing non-native fish and stocking for acclimatization follows rules that require the farmer to prepare a location scheme showing where the fish will be introduced, the species of fish to be acclimatized, their biological characteristics and source of acquisition, how technologies and fishery reclamation works will be applied, the volume of fish production, the chief characteristics of the fish production facility, energy 
consumption, types of feed to be used, and types and amounts of waste. There are no specific laws regulating the stocking of non-native species in Georgian legislation.

\subsubsection{Regulations on recreational fisheries}

Recreational fishing in Armenia is allowed through an annual license, which defines the species, the number of adult individuals, and the area and time of fishing. A recreational fishery may be operated in Azerbaijan without any special permits, meaning that no license is needed. There are some limitations regarding the place and time of fishing and the size of the fish. For example, from July 1 to April 30 in the river mouths at the Caspian Sea, an angler can catch up to $5 \mathrm{~kg}$ of the Black Sea roach, Rutilus frisii (Nordmann, 1840), with a total body length no less than $35 \mathrm{~cm}$. Recreational fishing is free in Georgia, however, the allowed fishing gear and methods are defined in the Technical Agreement on Fishing and Protection of Fish Stocks. The recreational fisheries are monitored at random or based on anonymous reports by the Department of Environmental Supervision (DES) of MEPAG.

What all SC countries have in common with regard to recreational fishing is that anglers are not obligated to report their catches and no statistical data is collected on the number of anglers, fished species and amounts, or even the types of licenses. Accordingly, there is no way to evaluate the contribution of recreational fisheries or to judge the effectiveness of the existing poorly developed regulations. Local fishers often have little knowledge of the risks and intentionally introduce non-native species or bring in native fish from other populations to 'support local stocks' (authors' observations).

\subsection{List of non-native fish species}

In total, 27 records of non-native species were surveyed in the SC countries of Armenia, Azerbaijan, and Georgia (Tab. 2). Among these taxa, eight species were translocated from the Black to the Caspian Sea basin and six species were unable to survive in the wild (Tab. 2). In Armenia, there were 16 non-native fish species among which, three (Gobio artvinicus, Perca fluviatilis and Sander lucioperca) were translocated and three (Anguilla anguilla, Ictalurus punctatus and Mylopharyngodon piceus) could not survive in natural water bodies. In Azerbaijan, there were 17 non-native fish species, from which five (Gasterosteus aculeatus, Chelon auratus, C. saliens, G. artvinicus and Salmo gegarkuni) were translocated and two (Mugil cephalus and Oncorhynchus kisutch) could not survive in the wild. In the western part of Georgia, eight non-native species were recorded while there were 16 in the eastern part of the country. Among these 16 species, four (G. artvinicus, P. fluviatilis, Salmo gegarkuni and Syngnathus abaster) were translocated and one species (Oreochromis niloticus) could not survive in wild. There were eight non-native species commonly occurring in all three countries: Carassius gibelio, Ctenopharyngodon idella, Gambusia holbrooki, Gobio artvinicus, Hypophthalmichthys molitrix and $H$. nobilis, Oncorhynchus mykiss, and Pseudorasbora parva (Tab. 2). There were 15 species that have become established in SC countries (Tab. 2).

\subsubsection{Notes on non-native species currently living in the wild}

\section{Coregonidae}

Coregonus albula is native to the Baltic Sea basin, lakes of the upper Volga River drainage, and also in some lakes of the White Sea basin and the North Sea basin (Kottelat and Freyhof, 2007). It was introduced from the Volkhov hatchery at Lake Ladoga (Russia) to southern Georgia, in Lakes Paravani and Tabatskuri during the 1930s (Barach, 1941; Elanidze, 1983; Japoshvili, 2004; 2012). In the beginning, this species was commercially very important and local hatcheries were involved in artificial reproduction of $C$. albula and release of fry into the lake (Japoshvili, 2012). As of 2005, these hatcheries ceased operation and it was expected that C. albula populations would become extinct over time. However, twelve years later young individuals were found in Saghamo Lake, which is connected to Paravani Lake by the Paravani River. This meant that they had become naturalized in the area, although the population density was extremely low (Kuljanishvili et al., 2018).

Commercially valuable species such as Coregonus sp. and C. ludoga from Ladoga Lake, and C. maraenoides from Chudskoe Lake were introduced to Sevan Lake in Armenia from 1924-1927, to support fish production (Barach, 1940; Dadikyan, 1964). During these three years, these coregonids were transported in the form of fertilized eggs from the Volkhov Hatchery in Russia, and already in 1927, fish farms around the lake reproduced whitefishes and released them into the lake (Dadikyan, 1964). Later on, these species were interbred (Mailyan, 1957) and a hybrid form arose as a new subspecies C. lavaretus sevanicus (Dadikyan, 1986). Because of insufficient taxonomic evidence, Kuljanishvili et al. (2020) reported the Sevan Lake whitefish as Coregonus sp. Sevan Lake coregonids are still commercially valuable and their populations are self-sustainable as no artificial propagation occurs in the lake. In addition, it is forbidden to fish in Sevan Lake during the breeding period. According to Elanidze (1983) in 1930, C. ludoga was introduced from the Volkhov hatchery at Ladoga Lake to Tabatskuri Lake in Georgia. For some reason, however, the species was not recorded for the past several decades.

\section{Cyprinidae}

Although Carassius gibelio is considered to be native to an area from central Europe to Siberia and eastern Asia (Rylková et al., 2013), its origin still remains unknown because of the incomplete introduction history and confusion with Carassius spp. (Kottelat and Freyhof, 2007). The species introduced into Armenia came from the Odessa region of the Ukraine in the 1960 s or 1970s together with the Chinese carps (Pipoyan, 1993, 2012; Pipoyan and Rukhkyan, 1998). Later, during the acclimatization of the herbivorous Chinese carps, Carassius gibelio was also accidentally introduced and spread to most of the water bodies in Azerbaijan and was spotted for the first time in the small Kyzylagach Bay in 1986 (Musayev et al., 2004). During the same period, C. gibelio was also recorded in Paliastomi Lake (western Georgia) (Daraselia, 1985). Its introduction into Georgia was most likely unintentional. As discussed by Japoshvili et al. (2013), this species was 
T. Kuljanishvili et al.: Knowl. Manag. Aquat. Ecosyst. 2021, 422, 32

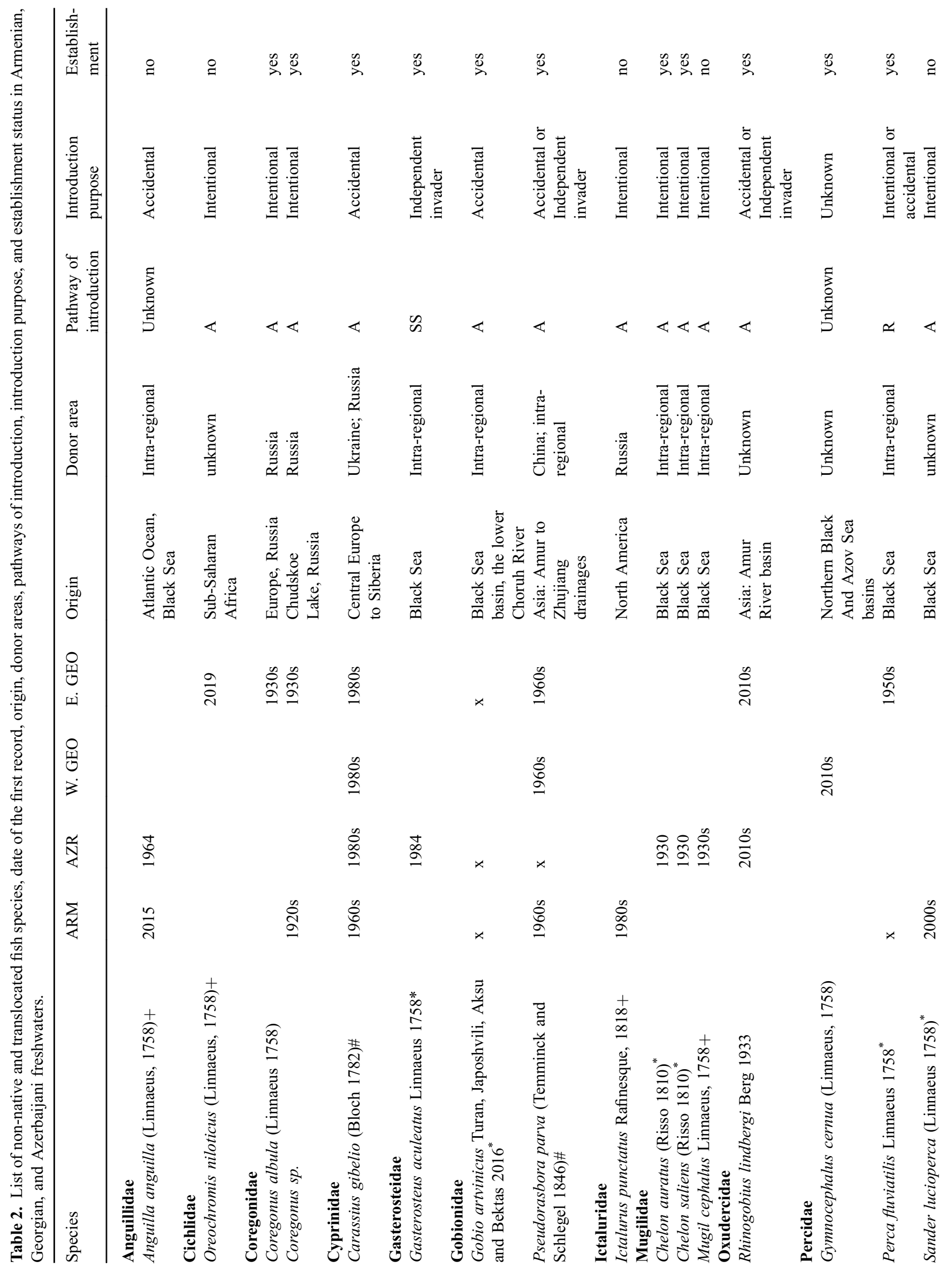


T. Kuljanishvili et al.: Knowl. Manag. Aquat. Ecosyst. 2021, 422, 32

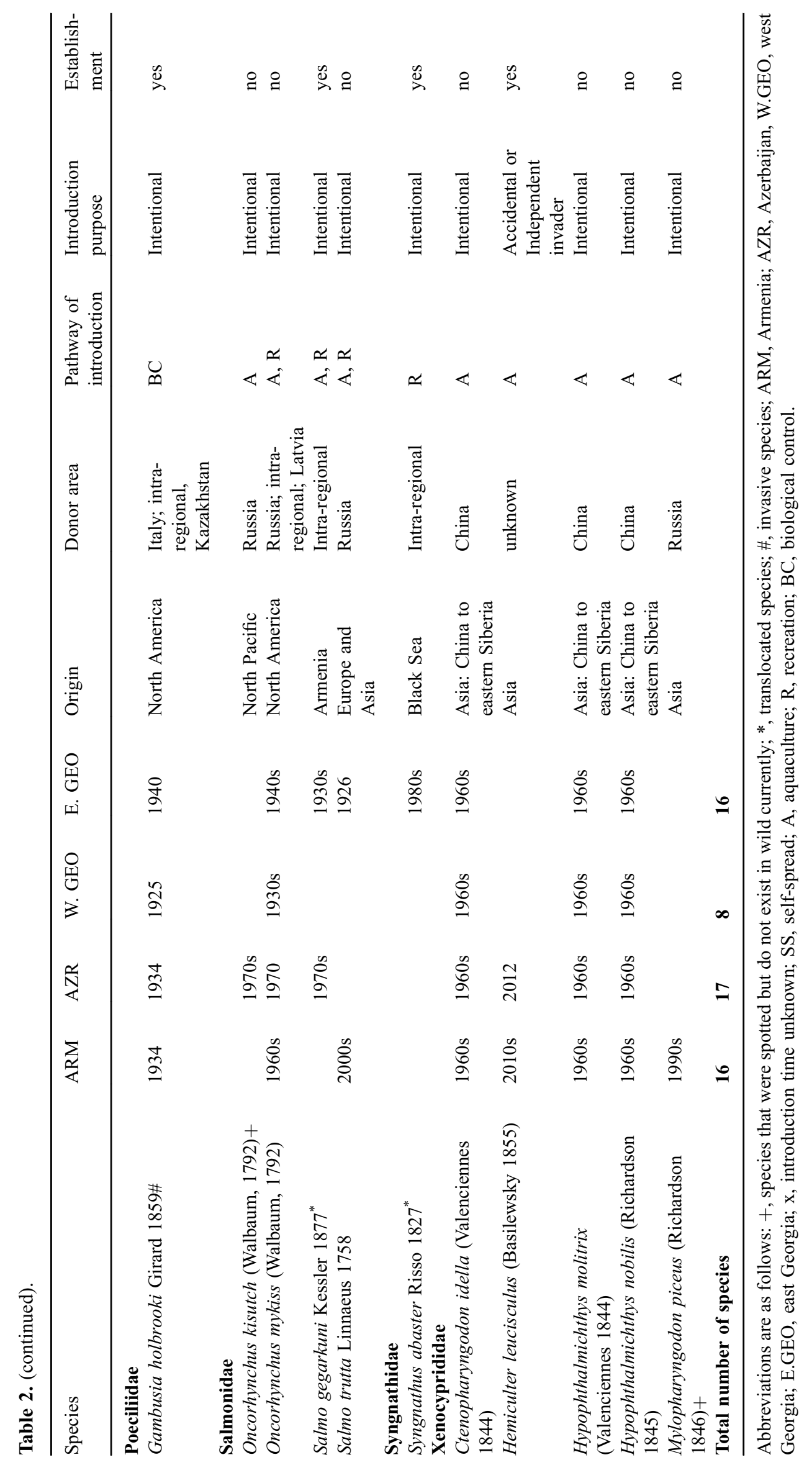


mistakenly introduced as, or with Cyprinus carpio, and it was spread to different water bodies by local people later (Japoshvili et al., 2013). According to local anglers, in the 1980 s, tons of $C$. gibelio fry were released in the Alazani River from local hatcheries that were raising $C$. carpio previously introduced from Russia. However, this action was not documented and there is no other evidence except the statements of the fishers. Today, $C$. gibelio is distributed in almost every water body and is usually the dominant species, especially in stagnant water (Japoshvili et al., 2013; Japoshvili et al., 2017; Kuljanishvili et al., 2017; 2020). Also, it is worth noting that in this region, $C$. gibelio can flourish in very harsh conditions such as Madatapa Lake, which at 2,100 meters above sea level is frozen almost six months out of the year (Japoshvili et al., 2017). Carassius gibelio is considered as one of the most aggressive and invasive species worldwide (Paulovits et al., 1998; Vetemaa et al., 2005; Mahmoud et al., 2009; Ribeiro and Leunda, 2012; Wouters et al., 2012; Simonović et al., 2013; Copp et al., 2016; Ruppert et al., 2017), although its effect on native fishes and ecosystems in the SC area is unknown.

\section{Gasterosteidae}

Gasterosteus aculeatus is a translocated species. It is native to the Black Sea basin and has been dispersed to the Caspian Sea basin and into Azerbaijan. The species appeared there for the first time in 1984 (Guliyev, 2006; Bogutskaya et al., 2013) and was an independent invader. The building of the Volga-Don canal opened a way for this species to disperse into the Caspian Sea basin (Bogutskaya et al., 2013) and it is now widely distributed throughout the Azerbaijani coast of the Caspian Sea and into the river mouths (Ibrahimov and Mustafayev, 2015). The fish enters the rivers during reproduction (Yusifov et al., 2017).

\section{Gobionidae}

Gobio artvinicus is a recently described species in the Black Sea basin from the lower Coruh River in Turkey (Turan et al., 2016). Kuljanishvili et al. (2020) proposed that $G$. artvinicus in the Kura-Aras system is alien species translocated from the Black Sea basin. However, there is no detailed information available when or for what reason this species was translocated, but its introduction was likely accidental and related to aquaculture activities. Currently, this species is widely distributed in the Kura-Aras system. It should also be mentioned that the species reported from the Metsamor River as Gobio gobio by Pipoyan (1998) and found also by Levin and Rubenyan (2010) is most probably G. artvinicus (Kuljanishvili et al., 2020).

Pseudorasbora parva is native to the Amur to Zhujiang River drainages in Asia (Kottelat and Freyhof, 2007). It was introduced into Armenian and Georgian water bodies from East Asian countries in the 1960s (Elanidze, 1983; Shonia et al., 2010; Pipoyan, 2012; Ninua et al., 2013; Pipoyan and Arakelyan, 2015). However, this species was discovered in Azerbaijan as late as 2008 (Karabanov et al., 2013), although this does not mean that the species was introduced in that year. In Armenia and Georgia, this species was accidentally introduced together with Hypophthalmichthys nobilis or
Ctenopharyngodon idella fry that were being imported from China at this time (Pipoyan, 2012; Ninua et al., 2013). However, in Azerbaijan, it was suggested that this species penetrated from Armenian water bodies through the Akstafa River. This species has established viable populations in the area and is now very common in almost every water body in the region, even at the relatively high altitude of Kartsakhi Lake at 2000 meters above sea level (Kuljanishvili et al., 2020). Since this species is known to have a huge negative impact on the native environment where it is introduced (Gozlan et al., 2005; Pinder et al., 2005), some adverse consequences of its introduction to the SC are expected.

\section{Mugilidae}

Chelon auratus and C. saliens are native to the Black Sea basin, and both species were translocated to the Caspian Sea basin in 1902. The first attempt to introduce them by Russian fish farmers was not successful, but another attempt in the 1930s resulted in the acclimatization of these two species in the Caspian Sea basin (Bogutskaya et al., 2013). Both species formed self-sustaining populations (Ibrahimov and Mustafayev, 2015) with current distributions over the entire Caspian sea basin (Bogutskaya et al., 2013; Yusifov et al., 2017). Moreover, these fish are also found in the brackish and fresh waters of the Caspian Sea coast (authors' observations).

\section{Oxudercidae}

Rhinogobius lindbergi is a newly recorded non-native fish species in the SC part of the Caspian Sea basin. Its native range is in the Amur River drainage and it is widely introduced in western Asia (Sadeghi et al., 2019), but the exact source from which the species was introduced has not been confirmed. Most probably it entered the SC rivers no earlier than the 2010s and today the species is distributed only in the eastern part of Georgia and Azerbaijan (Epitashvili et al., 2020; Japoshvili et al., 2020; Kuljanishvili et al., 2020). It is assumed that this species is likely to be already present in the Black Sea basin (Kuljanishvili et al., 2020). The vector for this species introduction in the region was either aquaculture or accidental, as it was introduced to Central Asia and Kazakhstan together with Chinese carps (Vasil'eva, 2007). Natural spread from neighbouring countries is also possible. This species is well established and seems to be abundant in eastern Georgian rivers (Epitashvili et al., 2020).

\section{Percidae}

Gymnocephalus cernua is distributed in the North, Baltic, Black, Azov and Caspian Sea basins (Kottelat and Freyhof, 2007). This species has not been recorded as native in the area of the SC. This species was recorded in the wild for the first time by Epitashvili et al. (2020) in the Rioni River of western Georgia. It's introduction is assumed to have been in the late 2010 s, although it is unclear how it could have overcome the natural barriers and appeared in west Georgia. Gymnocephalus cernua has become established, and is even invasive, in France, northern Italy, northern Great Britain, and the Great Lakes in North America (Kottelat and Freyhof, 2007), 
Germany, Austria, Switzerland and Norway (Gutsch and Hoffman, 2016). If established, this species might create competitive pressure for the native Perca fluviatilis (Lorenzoni et al., 2009).

Perca fluviatilis is native to the Black Sea basin and was not recorded in eastern Georgia until the early 1960s (Barach, 1964). In the 1950s it appeared in the Alazani River after Mingachevir Reservoir construction (Elanidze, 1983). This species also appeared in the Ararat region in Armenia (Kuljanishvili et al., 2020). Currently, this species is being translocated from western Georgian water bodies (where it is native) to the eastern ones by local fishers for angling purposes. It is commonly distributed in many eastern Georgian water bodies such as the Algeti and Tbilisi Reservoirs, Bareti, Bazaleti, Lisi, Turtle, and other lakes. Accidental occurrences of P. fluviatilis in the Ararat Region in Armenia might be connected to fishing activities (Pipoyan, 2020). Its establishment has not been reported in Armenia.

Sander lucioperca is native to the Black and Caspian Sea basins. This species was not recorded in Armenia before 2000. It has been caught in the Aras River at the Agarak-Megri district (Pipoyan and Tigranyan, 2002; Pipoyan, 2012) and was also recorded by Levin and Rubenyan (2010) in the Aras River. Though not officially reported, the repeated findings indicate the existence of established populations in Armenia, but the vector of introduction of this species is unknown.

\section{Poeciliidae}

Gambusia holbrooki is native of North America and was introduced into Georgia from Italy in 1925 by Dr. Rukhadze as a biological pest control agent against mosquitoes transmitting malaria, and since 1940, it has been introduced into the whole Georgian territory (Barach, 1941; Elanidze, 1983; Ninua et al., 2013). In Armenia, it was introduced for the same purpose from Georgia in 1934 (Dadikyan, 1986; Pipoyan, 2012). In Azerbaijan, it was also introduced in 1933-1934 (Abdurakhmanov, 1966) from Kazakhstan (Dengina, 1946) for mosquito control (Dengina, 1946). Gambusia holbrooki is acclimatized and has spread throughout the water bodies of Azerbaijan. Currently, this species is distributed widely and is considered invasive in the SC (Kuljanishvili et al., 2020). In addition, the appearance of the closely related $G$. affinis is also expected in SC since these species were and still are frequently misidentified (Vidal et al., 2010). Thus, more data is needed to better understand the distribution and diversity of Gambusia species in the SC.

\section{Salmonidae}

Oncorhynchus mykiss is native to North America with a range from the Pacific basin to northern Mexico. It is also native from Kamchatka to the lower Amur drainage in Asia (Kottelat and Freyhof, 2007). It was introduced into the USSR in Leningrad and the Kursk regions, and from the Kursk region, it was introduced into the Black Sea basin in 1936-1940 (Ninua and Japoshvili, 2008). Subsequently, it was introduced into the Tbilisi, Tkibuli, Shaori, Kumisi and other reservoirs in the region (Ninua et al., 2013). In Armenia, it was introduced from Georgia (Abkhazia region) in the 1960s-70s (Pipoyan, 2012). In Azerbaijan, it was introduced from Latvia, from the hatcheries in Russia and Abkhazia during the 1970-80s (Guliyev, 2006; Ibrahimov and Mustafayev, 2015) for aquaculture. This species is also very popular in recreational fisheries and anglers frequently release fry in reservoirs. Therefore, this species accidentally occurs in the wild throughout the SC (authors' observation, Levin and Roubenyan, 2010; Pipoyan, 2012). Despite this fact, selfsustaining populations of this species have not yet been reported in any of the SC countries.

Salmo gegarkuni is endemic to Sevan Lake, Armenia. This species was introduced into Georgia in the 1930s, first to Tabatskuri Lake in 1930-35, then in Paravani Lake in 1970, and in Tbilisi Reservoir around the 1980s. It was released into the Azerbaijani reservoirs and lakes in the 1970s (e.g., Maralgel Lake in 1977) for aquaculture (Elanidze, 1983; Musayev et al., 2004; Kuljanishvili et al., 2020). It was established in natural water bodies and still occurs in Georgia in the Tbilisi Reservoir and possibly also in mountain lakes of the Kalbajar region of Azerbaijan. Yusifov et al., (2017) reported that after the introduction of S. gegarkuni (named as S. ischchan) in the Kalbajar region, the native trout species populations decreased in abundance to the point where they were included on the Red List of Endangered Species in Azerbaijan.

Salmo trutta is native to the Atlantic, North and White Sea basins in Europe from Spain to the Chosha Bay in Russia (Kottelat and Freyhof, 2007). It was introduced from the Baltic Sea basin to a fish farm in Tbilisi, Georgia, from which fish were transported to a specifically constructed fish farm in the Natakhtari village (the Kura River drainage) in 1926 and this procedure was instigated by F. F. Kavrajsky (Dzerzhavin, 1941). In Armenia, it was introduced from Europe since the 2000s by farmers under the commercial name 'trout' together with $O$. mykiss. Some were released or accidentally appeared in open waters in Armenia (authors' observation). In Georgia, $S$. trutta has not been recorded after its introduction. However, in Armenia, this fish continues to be valued for use in recreational fisheries (authors' observation). To the best of our knowledge, $S$. trutta should not form sustainable viable populations in Armenia (authors' observation). It should be noted that both older and some recent references erroneously mentioned the taxon, S. trutta. This was the result of an obsolete taxonomic approach in which many forms or subspecies of S. trutta were used, e.g. S. $t$. fario and $S$. $t$. caspius for the fauna of Armenia, Azerbaijan and Georgia (Barach, 1940; 1941; Berg, 1949; Elanidze, 1983; Gabrielyan, 2001; Pipoyan and Tigranyan, 2002; Ninua and Japoshvili, 2008; Pipoyan, 2012; Ninua et al., 2013). In this case, the taxon Salmo trutta was used for native Salmo caspius, not introduced S. trutta.

\section{Syngnathidae}

Syngnathus abaster is a marine and brackish water species native to the Black Sea, but is also able to survive in fresh water (Kiryukhina, 2013a; b; Tereshchenko et al., 2016; Didenko et al., 2018; Marenkov 2018). It was translocated from the Black Sea basin in the western part of Georgia to the eastern part of the country in the 1980s. As reported by Kuljanishvili et al. (2021b), the species was translocated by local hobbyists to the Tbilisi Reservoir, which is locally referred to as 'Tbilisi 
Sea'. This translocation was intentional because of the marine name of the freshwater reservoir. Currently, this species has established self-sustainable populations in the reservoir and could be further distributed into nearby water bodies.

\section{Xenocyprididae}

Ctenopharyngodon idella, Hypophthalmichthys molitrix and $H$. nobilis all have a similar introduction history in the SC. These species were introduced from China in the 1960s for aquaculture to all three countries almost simultaneously (Abbasov, 1972) and have continued to be released into the wild up till now (Elanidze, 1983; Dadikyan, 1986; Gabrielyan, 2001; Ninua and Japoshvili, 2008; Naseka and Bogutskaya, 2009; Pipoyan, 2012; Bogutskaya et al., 2013). These species were unable to sustain populations there and for that reason, their regular stocking has continued.

Hemiculter leucisculus is native to southeastern Asia and the Amur River basin. The species appeared on the Iranian shores of the Caspian Sea in the 1990s as an accidental contaminant of Chinese carp parcels (Zareian et al., 2015). It was recorded in Azerbaijan for the first time in 2012 (Mustafayev et al., 2015), but the exact time of its introduction and the pathways are still unknown. Most probably it entered from the neighbouring areas, where it was already introduced (Mustafayev et al., 2015). H. leuciscus was also recently discovered in Armenia, in the Arpa River by Pipoyan and Arakelyan (2021). The first introduction date and pathway of this species introduction in Armenia is unknown, but it probably penetrated from neighbouring areas. The species is currently well established in the Caspian Sea basin and Kuljanishvili et al. (2020) and it is assumed that it will soon penetrate the Black Sea basin.

\subsubsection{Notes on non-native species that no longer occur} in the wild.

\section{Anguillidae}

Anguilla anguilla is native to the Atlantic Ocean and is distributed in all European rivers that flow into the Mediterranean, North and Baltic Seas, with some individuals entering the Black Sea (Kottelat and Freyhof, 2007). Passing through the Volga-Baltic waterway, A. anguilla accidentally appeared in the Volga River, and from there made its way into the Caspian Sea. Since 1964, individuals of this species have been found at the mouths of rivers in Azerbaijan (Abdurakhmanov, 1966; Ibrahimov, 2012). In 2015, it was also observed in the middle Aras River (Pipoyan, 2015), which is classified as an accidental occurrence rather than as an introduction record (Kuljanishvili et al., 2020).

\section{Cichlidae}

Oreochromis niloticus is native to Sub-Saharan Africa and it is one of the most cultured fishes worldwide (Trewavas, 1983). Because of this reason, this species has been widely introduced for aquacultural purposes to different countries, which had led to its successful establishment in some areas of USA (Zambrano et al., 2006) and Brazil (Britton and Orsi, 2012). In summer of 2019, Oreochromis sp. has appeared to the local angler's catch in the small River Baisubniskhevi, eastern Georgia (Lagodekhi Region) (Kuljanishvili et al., 2021a). Probably it appeared in the river from the nearby fish farms, where the owners might have been stocking tilapias for aquaculture. Local angler collected around 10 individuals and provided photographs to the authors. According to our observation, the fish was identified as $O$. niloticus. And after repeated sampling in the same year, later in the season, the fish did not appear in our catch. However, this case needs attention, since it was not believed that $O$. niloticus could establish in temperate US, however, it was later shown that they have established successful populations (Grammer et al., 2012). Since the climatic conditions in the eastern Georgia fluctuates from cold mountainous to humid subtropical type it is necessary to monitor the success of this species establishment in the area.

\section{Ictaluridae}

Ictalurus punctatus, the venomous catfish native to North America, was brought to Armenia from Krasnodar, Russia in 1981, 1983, 1991. It is currently absent in the wild in the region (Pipoyan and Tigranyan, 1998, 2002; Pipoyan 2012).

\section{Mugilidae}

Mugil cephalus is native to the Black Sea basin. It was brought together with Chelon auratus and C. saliens, from the Black Sea and released into the Caspian Sea for acclimatization in 1930-34. Unlike Chelon auratus and C. saluens, $M$. cephalus could not adapt to local environmental conditions in the Caspian Sea and disappeared (Bogutskaya et al., 2013).

\section{Salmonidae}

Oncorhynchus kisutch is originally from the northern Pacific Ocean. This species was transported from Kamchatka in Russia to Azerbaijan in 1977-83, to the Chaykend fish hatchery in the form of fertilized eggs. After incubation, the hatched fry were released into the Caspian Sea (Musayev et al., 2004). However, there is no data on the results of the acclimatization of this fish and no records from the wild.

\section{Xenocyprididae}

Mylopharyngodon piceus is native to the Amur River basin to southern China and was introduced in Armenia from Krasnodar, Russia, in 1990. It was reported as an acclimatized species by (Pipoyan and Tigranyan, 1998; 2002), but without giving any details of the species distribution in the wild (Levin and Rubenyan, 2010). Later, Pipoyan (2012) reported that this species was distributed in the Metsamor River drainage; however, due to discontinuation of artificial reproduction, it disappeared from the inland waters of Armenia (Pipoyan, 2012). Unless there is new evidence of this species being caught in the wild in Armenia, we believe that this species should be taken off the list of non-native species of Armenia.

\subsection{Summary of the list of non-native fish species}

\subsubsection{Donor areas}

To summarize the previous section, the most important donor area for fish introduction was intra-regional spread (Tab. 2). In total, 12 species were spread within the 


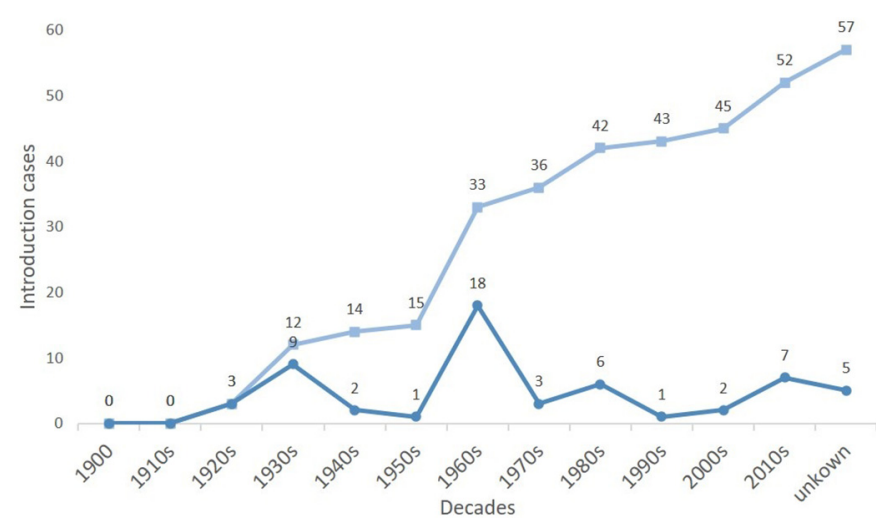

Fig. 2. Number of introduction cases by the decades in Armenia, Azerbaijan and Georgia together expressed by dots; and total number of introduction cases by the decades expressed by squares. Note that, the total number of cases is 57 since there are species that were introduced in different times in different countries.

SC countries, mostly intentionally (Tab. 2). These species were Anguilla anguilla, Gasterosteus aculeatus, Gobio artvinicus, Pseudorasbora parva, Chelon auratus, C. saliens, Mugil cephalus, Perca fluviatilis, Gambusia holbrooki, Oncorhynchus mykiss, Salmo gegarkuni, and Syngnathus abaster.

The largest number of non-native species was introduced from Russia (Tab. 2). This is a consequence of the fact that all three countries were part of the Soviet Union in the past, because most introductions happened during that period. Eight species were introduced intentionally. These are Coregonus albula, Coregonus sp., Carassius gibelio, Ictalurus punctatus, Oncorhynchus kisutch, O. mykiss, Salmo trutta, and Mylopharyngodon piceus (Tab. 2). Four species widely used in aquaculture were introduced intentionally in all three SC countries from China mainly because this country is the main provider of the species that are easy to keep and culture in ponds, and pond aquaculture is currently very popular in this region (Tab. 2). These species are Pseudorasbora parva, Ctenopharyngodon idella, Hypophthalmichthys molitrix, and H. nobilis (Tab. 2). Two non-native introductions came from Europe (Tab. 2): Gambusia holbrooki was introduced from Italy into Georgia, and rainbow trout Oncorhynchus mykiss came from Latvia to Azerbaijan (Tab. 2). One species, Carassius gibelio, came from Ukraine into Armenia (Tab. 2), and Gambusia holbrooki was introduced to Azerbaijan from Kazakhstan. The donor area is unknown for five cases (Tab. 2). From where Sander lucioperca got to Armenia, Hemiculter leucisculus to Azerbaijan, Rhinogobius lindbergi to Azerbaijan and Georgia, Gymnocephalus cernua and Oreochromis niloticus to Georgia is unknown (Tab. 2).

\subsubsection{Decades of introductions}

There were four peaks of non-native species introductions in the 1930s, the 1960s, 1980s, and the 2010s with 9, 18, 6 and 7 new introduction events (Fig. 2). The remaining decades were characterized by fewer introductions (Fig. 2). While most of the introductions and translocations of local species, both intentional and unintentional, happened during the Soviet Era before the 1990s, the species introductions also continued during the last 30 years of the later period and tended to increase in 2010 s.

It is not surprising that the largest number of introductions happened during the Soviet era as this period was characterized in general by a significant increase in new introductions and translocations worldwide (Copp et al., 2005). The 1920s-30s is also an interesting period when intensive introductions for aquaculture purpose were pioneered by the scientist, Dr. Rukhadze, and Prof. Derzhavin in the SC. It is also known that during the Soviet regime, fish introductions for acclimatization and stocking for aquaculture were encouraged by the central government (Copp et al., 2005). It should be also mentioned that the recent decade was characterised with high number of non-native species, meaning that developing of monitoring strategies is crucial.

\subsubsection{Pathways of introductions}

The basic pathway for fish introductions in the SC with 18 cases out of 27 introductions, was aquaculture followed by aquaculture and recreational fisheries (with three cases), and lastly, recreational fisheries (with two cases) (Tab. 2). Gambusia holbrooki was only species, that was introduced for biocontrol purposes and only species such as G. aculeatus are thought to be independent (self-spreading) intruders to new areas in the SC (Tab. 2). Except for a few cases, all introductions were intentional with direct human assistance (Tab. 2). This includes target species and accompanied non-target species introductions.

\subsubsection{State of non-native fish species establishment}

Out of 27 non-native fish species recorded, 15 are currently established. The remaining 12 species are dependent on human support (Tab. 2). Among these 15 established species, Carassius gibelio, Pseudorasbora parva and Gambusia holbrooki are of primary importance because of their aggressive, invasive behavior. Before reliable risk/impact assessments of these species will be done, we have to rely on existing literature to assess their invasive potential. For instance, $C$. gibelio is considered one of the most successful invasive fish worldwide (Copp et al., 2005; Gozlan et al., 2010) with a negative impact on the environment because of its foraging behaviour and unusually high abundances (Vetemaa et al., 2005; Lusková et al., 2010). The presence of C. gibelio is known to increase water turbidity (Crivelli, 1995) and lead to alterations in the nutrient cycle (Paulovits et al., 1998). It negatively affects native species including plants and animals in terms of grazing pressure and by direct competition with natives (Gaygusuz et al., 2007; Ribeiro and Leunda, 2012; Tarkan et al., 2012; Ruppert et al., 2017). C. gibelo may also cause the introduction of non-indigenous parasites and pathogens into newly invaded areas (Žitnan, 1974; Mahmoud et al., 2009). Like C. gibelio, Pseudorasbora parva is also a widely distributed invasive species. Once established, it creates dense populations that become dominant and compete aggressively with native species for resources (Britton et al., 2007). It is also known to feed on the eggs and larvae of native species (Pinder et al., 2005). Moreover, it is a host of Sphaerothecum destruens, the novel fish pathogen in Europe (Gozlan et al., 2010). Gambusia holbrooki is known to have a negative impact on native fish and amphibian fauna 
(Hamer et al., 2002; Alcaraz et al., 2008). Because of its rapid reproduction, it can quickly reach high abundance, which makes this species more invasive (Benejam et al., 2009). Its feeding habit plays an important role in shaping the community of zooplankton (Margaritora et al., 2001) and it successfully competes for food with native species (Scalici et al., 2007). These well-known invasive species are currently widespread and frequently dominant in the whole SC area, and have already had a significant impact on the native fauna and ecosystems. There has been no attempt to quantify the effects of invasive fish species in the SC countries, or to extrapolate their future impact if left unchecked. Thus, it is not surprising that no strategy exists for mitigating the impact of invasive species in Armenia, Azerbaijan, and Georgia.

\section{Conclusions}

For many decades, there has been little attention paid to the history of introduction and the status of non-native fish species in the SC countries of Armenia, Azerbaijan, and Georgia. To the best of our knowledge, this study is the first attempt to establish a reliable background for risk assessment of non-native species and evaluation of their impact on the area. This paper should help the national decision-makers to categorize native and non-native species and to improve legislation for regulating introduction and stocking of non-native species, aquaculture production and the pet trade, which our study revealed are poorly designed and not consistent across the three SC countries. These countries share the same river basin, the Kura-Aras, and up to now, there has been no initiative among them addressing the problem of invasive freshwater fishes (or other invasive taxa such as crustaceans and molluscs), either at the governmental or the academic level. Thus, transboundary monitoring schemes and data-sharing systems do not exist. In general, the lack of rules or enforcement of existing standards regarding introductions and translocations have contributed to an increase in the number of non-native species, which endangers native organisms (Copp et al., 2005) and threatens to cause serious socio-economic losses in the region. Therefore, we strongly encourage substantive discussions and planning to deploy systems designed to protect the highly vulnerable freshwater ecosystems in the Caucasus biodiversity hotspot.

Acknowledgements. The study was supported by the Czech University of Life Sciences Internal Grant Agency (\#20132018) to T.K. J.P and L.K. Authors would like to thank Archil Partsvania and Nona Khelaia from MEPAG, Nana Mdivani from the National Food Agency of Georgia, and Samvel Baloyan from the MERA for their help and communication; Gohar Arakelyan for translation from Armenian to English and Gary Bentley from Peerwith for language editing.

\section{References}

Abbasov HS. 1972. The biological basis of the cultivation of fishes, which breed in the spills of lakes and rivers, Elm (in Azeri) Baku, p. 188.
Abdurakhmanov UA. 1966. Fauna of Azerbaijan: Fishes, Publishing house of the Azerb. Acad. of Sci (in Azeri) Baku, p. 223.

Abell R, Thieme ML, Revenga C, et al. 2008. Freshwater ecoregions of the world: a new map of biogeographic units for freshwater biodiversity conservation. BioScience 58: 403.

Alcaraz C, Bisazza A, García-Berthou E. 2008. Salinity mediates the competitive interactions between invasive mosquitofish and an endangered fish. Oecologia 155: 205-213.

Barach G. 1941. Freshwater fishes. In: Fauna of Georgia (Volume 1), Metsniereba (in Russian) Tbilisi, p. 288.

Barach G. 1964. Lake reservoirs of Georgia and their fishery value, Sabchota Sakartvelo (in Russian) Tbilisi, p. 192.

Barach GP. 1940. Fishes of Armenia. Proc Sevan Hydrolog Stat 6: 5-70.

Benejam L, Alcaraz C, Sasal P, Simon-Levert G, García-Berthou E. 2009. Life history and parasites of the invasive mosquitofish (Gambusia holbrooki) along a latitudinal gradient. Biolog Invas 11: 2265-2277.

Berg LS. 1949. Freshwater fishes of the USSR and adjacent countries, Israel program for scientific translations (in Russian) Jerusalem, p. 496.

Bij de Vaate A, Jazdzewski K, Ketelaars HAM, Gollasch S, Van der Velde G. 2002. Geographical patterns in range extension of PontoCaspian macroinvertebrate species in Europe. Can J Fish Aquat Sci 59: 1159-1174.

Bogutskaya N, Kijashko P, Naseka AM, Orlova MI. 2013. Identification keys for fish and invertebrates of the Caspian Sea. Vol. 1. Fish and molluscs, Tovarishestvo Naucnikh Izdanii KMK. (In Russian) Moscow, p. 443.

Britton JR, Orsi ML. 2012. Non-native fish in aquaculture and sport fishing in Brazil: Economic benefits versus risks to fish diversity in the upper River Paraná basin. Rev Fish Biol Fish 22: 555-565.

Britton JR, Davies GD, Brazier M, Pinder AC. 2007. A case study on the population ecology of a topmouth gudgeon (Pseudorasbora parva) population in the UK and the implications for native fish communities. Aquat Conserv 17: 749-759.

Central Intelligence Agency. 2020. The World Factbook. https:// www.cia.gov/library/publications/the-world-factbook/ (accessed October 20, 2020).

Copp GH, Bianco PG, Bogutskaya NG, et al. 2005. To be, or not to be, a non-native freshwater fish? Appl Ichthyol 21: 242-262.

Copp GH, Russell IC, Peeler EJ, et al. 2016. European non-native species in aquaculture risk analysis scheme - a summary of assessment protocols and decision support tools for use of alien species in aquaculture. Fish Manag Ecol 23: 1-11.

Crivelli AJ. 1995. Are fish introductions a threat to endemic freshwater fishes in the Northern Mediterranean region? Biolog Conserv 72: 311-319.

Dadikyan MG. 1964. Towards the Results of Intriduction of Coregonids (Coregonus lavaretus maraenoides Poljakow, C. lavaretus ludoga Poljakow) in the Lake Sevan. Proc Acad Sci Armenian SSR (in Russian) 17: 41-48.

Dadikyan MG. 1986. Fishes of Armenia, AN Arm SSR (in Russian) Yerevan, p. 245.

Daraselia TG. 1985. Existence of Carassius carassius in inland waters of Georgia. In: Kurashvili B, ed. Proceedings of the Conference of Young Scientists. Tbilisi: Institute of Zoology, $12-14$.

Dengina RS. 1946. Gambusia and its role in fisheries. Proceedings of the Institute of Zoology of the Academy of Sciences of Azerbaijan. SSR. Vol. 11 (in Russian) 41-73. 
Didenko A, Kruzhylina S, Gurbyk A. 2018. Feeding patterns of the black-striped pipefish Syngnathus abaster in an invaded freshwater habitat. Environ Biol Fish 101: 917-931.

Dzerzhavin AN. 1941. Replenishing the stocks of Caspian salmon, Izd. Inst. Zoolog. Azerbaidzh. fil. Akad. Nauk SSSR (in Russian) Baku, p. 74.

Elanidze R. 1983. Ichthyofauna of the rivers and lakes of Georgia, Metsniereba (in Russian) Tbilisi, p. 320.

Epitashvili G, Geiger MF, Astrin JJ, Herder F, Japoshvili B, Mumladze L. 2020. Towards retrieving the Promethean treasure: a first molecular assessment of the freshwater fish diversity of Georgia. Biodivers Data J 8: e57862.

Gabrielyan BK. 2001. An annotated checklist of freshwater fishes of Armenia. Naga ICLARM Quart 24: 23-29.

Gallardo B, Aldridge DC. 2013. Priority setting for invasive species management: risk assessment of Ponto-Caspian invasive species into Great Britain. Ecol Appl 23: 352-64.

Gaygusuz Ö, Tarkan AS, Gaygusuz ÇG. 2007. Changes in the fish community of the Ömerli Reservoir (Turkey) following the introduction of non-native gibel carp Carassius gibelio (Bloch, 1782) and other human impacts. Aquat Invas 2: 117-120.

Gozlan RE, St-Hilaire S, Feist SW, Martin P, Kents ML. 2005. Disease threat to European fish. Nature 435: 1046.

Gozlan RE, Britton JR, Cowx I, Copp GH. 2010. Current knowledge on non-native freshwater fish introductions. J Fish Biol 76: 751-786.

Grammer GL, Slack WT, Peterson MS, Dugo MA. 2012. Nile tilapia Oreochromis niloticus (Linnaeus, 1758) establishment in temperate Mississippi, USA: multi-year survival confirmed by otolith ages. Aquat Invas 7: 367-376.

Guliyev GN. 2006. New fish species in the Caspian Sea, in: Materials of first congress of the Azerbaijan society of zoologists (in Azeri) 367-369.

Gutsch M, Hoffman J. 2016. A review of Ruffe (Gymnocephalus cernua) life history in its native versus non-native range. Rev Fish Biol Fish 26: 213-233.

Hamer AJ, Lane SJ, Mahony MJ. 2002. The role of introduced mosquitofish (Gambusia holbrooki) in excluding the native green and golden bell frog (Litoria aurea) from original habitats in southeastern Australia. Oecologia 132: 445-452.

Ibrahimov SR. 2012. Parasites and diseases of fish of the Caspian Sea (ecological and geographical analysis, epizootological and epidemiological assessment), Elm (in Russian) Baku, p. 400.

Ibrahimov SR, Mustafayev NJ. 2015. Current Status of Azerbaijan Ichthyofauna. Proc Azerbaijan Inst Zool (in Azeri) 33: 58-68.

Japoshvili B. 2004. Some biological and morphometric characteristics of a vendace (Coregonus albula L.) of the Lake Paravani. Proc Georg Acad Sci 2: 97-100.

Japoshvili B. 2012. Long-term assessment of a vendace (Coregonus albula L.) stock in Lake Paravani, South Georgia. Biol Manag Coregonid Fishes 2008 63: 363-369.

Japoshvili B, Mumladze L, Küçük F. 2013. Invasive Carassius carp in Georgia: Current state of knowledge and future perspectives. Curr Zool 59: 1-13.

Japoshvili B, Lipinskaya T, Gajduchenko H, Sinchuk A, Bikashvili A, Mumladze L. 2020. First DNA-based records of new alien freshwater species in the Republic of Georgia. Acta Zool Bulgar 72: 545-551.

Japoshvili B, Mumladze L, Murvanidze L. 2017. The population of Carassius gibelio (Bloch, 1782) and its parasites in Madatapa Lake (South Georgia). Iran J Fish Sci 16: 793-799.

Jeschke JM, Bacher S, Blackburn TM, et al. 2014. Defining the impact of non-native species. Conserv Biol 28: 1188-1194.
Karabanov DP, Kodukhova YV, Mustafayev NJ. 2013. Topmouth gudgeon Pseudorasbora parva (Cyprinidae) - a new species in the ichthyofauna of Azerbaijan. Russ J Biol Invas 4: 133-138.

Kiryukhina NA. 2013a. Morphological variability in black-striped pipefish Syngnathus nigrolineatus in relation to its invasion into the Volga basin reservoirs. Russ J Biolog Invas 4: 149-155.

Kiryukhina NA. 2013b. Molecular and genetic variability in populations of Syngnathus nigrolineatus Eichwald 1831 and ways of expansion in the Volga River basins on the basis of mitochondrial DNA sequence analysis. Russ J Biol Invas 4: 249-254.

Koščo J, Košuthová L, Košuth P, Pekárik L. 2010. Non-native fish species in Slovak waters: origins and present status. Biologia 65: $1057-1063$

Kottelat M, Freyhof J. 2007. Handbook of European Freshwater Fishes. Kottelat, Cornol and Freyhof. Berlin, p. 646.

Kuljanishvili T, Japoshvili B, Mumladze L, Kalous L. 2017. Preliminary information about the occurrence of Prussian carp Carassius gibelio (Bloch 1782) in mountainous Lake Devdoraki (Caucasus, Georgia). 9th Workshop on biodiversity, Jevany $48-52$.

Kuljanishvili T, Mumladze L, Kalous L, Japoshvili B. 2018. Fish species composition, sex ratio and growth parameters in Saghamo Lake (Southern Georgia). Biologia 73: 93-100.

Kuljanishvili T, Epitashvili G, Freyhof J, et al. 2020. Checklist of the freshwater fishes of Armenia, Azerbaijan and Georgia. $J$ Appl Ichthyol 36: 501-514.

Kuljanishvili T, Epitashvili G, Japoshvili B, Patoka J, Kalous L. 2021a. Finding of nile tilapia Oreochromis niloticus (Cichliformes: Cichlidae) in Georgia, the South Caucasus. International Symposium on Aquatic Sciences and Resources Management 16-17 November 2020, IOP Conf. Series: Earth and Environmental Science 744, Bogor, West Java, Indonesia. 1-5.

Kuljanishvili T, Patoka J, Bohatá L, Rylková K, Japoshvili B, Kalous L. 2021b. Evaluation of the potential establishment of black-striped pipefish transferred by cultural drivers. Inland Waters 1-8.

Lenhardt M, Markovic G, Hegedis A, Maletin S, Cirkovic M, Markovic Z. 2011. Non-native and translocated fish species in Serbia and their impact on the native ichthyofauna. Rev Fish Biol Fish 21: 407-421.

Levin BA, Rubenyan AR. 2010. Annotated checklist of ichtyofauna of Armenia. In Pavlov DS, Gabrielyan BK, Krylov AB, eds. Ecology of Lake Sevan during a raise of its level. The results of Russian-Armenian biological expedition for hydroecological survey of Lake Sevan (Armenia) (2005-2009), Nauka DNTS (in Russian) Makhachkala, 229-242.

Lorenzoni M, Pace R, Pedicillo G, Viali P, Carosi A. 2009. Growth, catches and reproductive biology of ruffe Gymnocephalus cernuus in Lake Piediluco (Umbria, Italy). Folia Zool 58: 420-435.

Lusková V, Lusk S, Halačka K, Vetešník L. 2010. Carassius auratus gibelio - the most successful invasive fish in waters of the Czech Republic. Russ J Biol Invas 1: 176-180.

Magalhães ALB, Vitule J. 2013. Aquarium industry threatens biodiversity. Science 341: 547.

Mahmoud MA, Aly SM, Diab AS, John G. 2009. The role of ornamental goldfish Carassius auratus in transfer of some viruses and ectoparasites to cultured fish in Egypt: Comparative ultrapathological studies. Afr J Aquat Sci 34: 111-121.

Mailyan RA. 1957. Coregonids of Sevan Lake. Proc Sevan Hydrolog Stat (in Russian) 15: 137-195.

Manchester SJ, Bullock JM. 2000. The impacts of non-native species on UK biodiversity and the effectiveness of control. J Appl Ecol 37: $845-864$. 
Marenkov O. 2018. Abundance and biomass estimation of this summer individuals of alien fish species in Zaporizke reservoir. Ukrain J Ecol 8: 92-96.

Margaritora FG, Ferrara O, Vagaggini D. 2001. Predatory impact of the mosquitofish (Gambusia holbrooki Girard) on zooplanktonic populations in a pond at Tenuta di Castelporziano (Rome, Central Italy). J Limnol 60: 189-193.

Mastitsky SE, Karatayev AY, Burlakova LE, Adamovich BV. 2010. Non-native fishes of Belarus: Diversity, distribution, and risk classification using the Fish Invasiveness Screening Kit (FISK). Aquat Invas 5: 103-114.

Musayev MA, Quliyev ZM, Rehimov DB, et al. 2004. Vertebrates, volume III. In: Musayev MA, ed. The Animal World of Azerbaijan: Elm (in Azeri) Baku. 3-316.

Musil J, Jurajda P, Adámek Z, Horký P, Slavík O. 2010. Non-native fish introductions in the Czech Republic - species inventory, facts and future perspectives. J Appl Ichthyol 26: 38-45.

Mustafayev NJ, Ibrahimov ShR, Levin BA. 2015. Korean sharpbelly Hemiculter leucisculus (Basilewsky, 1855) (Cypriniformes, Cyprinidae) is a new species of Azerbaijan fauna. Russ $J$ Biol Invas 6: 252-259.

Myers N, Mittermeier RA, Mittermeier CG, da Fonseca GAB, Kent J. 2000. Biodiversity hotspots for conservation priorities. Nature 403: $853-858$

Naseka AM. 2010. Zoogeographical freshwater divisions of the Caucasus as a part of the west Asian transitional region. Proc Zool Inst RAS 314: 469-492.

Naseka AM, Bogutskaya NG. 2009. Fishes of the Caspian Sea: zoogeography and updated check-list. Zoosystem Rossica 18: 295-317.

Ninua N, Japoshvili B, Bochorishvili V. 2013. Fishes of Georgia, Tsignieri, Tbilisi, p. 180.

Ninua NS, Japoshvili BO. 2008. Check list of fishes of Georgia. Proc Inst Zool 23: 163-176.

Patoka J, Magalhães ALB, Kouba A, Faulkes Z, Jerikho R, Vitule JRS. 2018. Invasive aquatic pets: Failed policies increase risks of harmful invasions. Biodivers Conserv 27: 3037-3046.

Paulovits G, Tatrai I, Matyas K, Korponai J, Kovats N. 1998. Role of prussian carp (Carassius auratus gibelio Bloch) in the nutrient cycle of the Kis-Balaton Reservoir. Intem Rev Hydrobiol 83: 467-470.

Pinder AC, Gozlan RE, Britton JR. 2005. Dispersal of the invasive topmouth gudgeon, Pseudorasbora parva in the UK: A vector for an emergent infectious disease. Fish Manag Ecol 12: 411-414.

Pipoyan SKH. 2020. Finding river perch Perca fluviatilis (Actinopterygii, Percidae) in isolated reservoir in the Arararat region (Armenia). Biol J Armenia (in Russian) 1: 30-33.

Pipoyan SKH. 1993. Investigating morphological and biological characteristics of prussian carp Carassius auratus gibelio (Bolch, 1783 ) in different water bodies of Armenia. Yerevan State University.

Pipoyan SKH. 2012. Ichthyofauna of Armenia: stages of formation and current state, Palmarium Academic Publishing (In Rissian), p. 538.

Pipoyan SKH. 2015. Discovery of black eel Anguilla Anguilla in Armenian waters. Biol J Armen (in Russian) 3: 104-106.

Pipoyan SKH, Arakelyan AS. 2021. Finding of sharpbelly Hemiculter leuciscus (Basilewsky 1855) (Cypriniformes, Cyprinidae) in the Arpa River (Armenia). Biol J Armenia (in Russian) Accepted M.

Pipoyan SKH, Arakelyan AS. 2015. The distribution of topmouth gudgeon Pseudorasbora parva (Temminck et Schlegel, 1846) (Actinopterygii: Cyprinidae) in water bodies of Armenia. Russ $J$ Biol Invas 6: 179-183.
Pipoyan SKH, Rukhkyan RG. 1998. Reproduction and development of prussian carp Carassius auratus gibelio in water bodies of Armenia. Voprosy ikhtiologii (in Russian) 38: 353-358.

Pipoyan SKh, Tigranyan EA. 1998. Checklist of the fishes of Armenia. Biol J Armen (in Russian) 51: 258-265.

Pipoyan SKH, Tigranyan EA. 2002. Modern fish fauna of Armenia. $J$ Ichthyol (in Russian) 42: 601-604.

Piria M, Simonović P, Kalogianni E, et al. 2017. Alien freshwater fish species in the Balkans-Vectors and pathways of introduction. Fish Fish 138-169.

Povž M, Šumer S. 2005. A brief review of non-native freshwater fishes in Slovenia. J Appl Ichthyol 21: 316-318.

Ribeiro F, Leunda PM. 2012. Non-native fish impacts on Mediterranean freshwater ecosystems: current knowledge and research needs. Fish Manag Ecol 19: 142-156.

Ricciardi A. 2003. Predicting the impacts of an introduced species from its invasion history: an empirical approach applied to zebra mussel invasions. Freshw Biol 48: 972-981.

Ruppert JLW, Docherty C, Hamilton K, Macpherson L, Poesch MS. 2017. Native freshwater species get out of the way: Prussian carp (Carassius gibelio) impacts both fish and benthic invertebrate communities in North America Subject 4: 170400.

Rylková K, Kalous L, Bohlen J, Lamatsch DK, Petrtýl M. 2013. Phylogeny and biogeographic history of the cyprinid fish genus Carassius (Teleostei: Cyprinidae) with focus on natural and anthropogenic arrivals in Europe. Aquaculture 380-383: $13-20$.

Sadeghi R, Esmaeili HR, Zarei F, Esmaeili A, Abbasi K. 2019. The taxonomic status of an introduced freshwater goby of the genus Rhinogobius to Iran (Teleostei: Gobiidae). Zool Middle East 65: $51-58$.

Scalici M, Avetrani P, Gibertini G. 2007. Mosquitofish life history in a Mediterranean wetland. J Natl History 41: 887-900.

Shonia L, Kokosadze T, Japoshvili B. 2010. Biology and Ecology of Pseudorasbora parava in the Basaleti lake. Proc Georg Acad Sci 8: 76-81.

Simonović P, Tošić A, Vassilev M, et al. 2013. Risk assessment of non-native fishes in the Balkans Region using FISK, the invasiveness screening tool for non-native freshwater fishes. Mediterran Mar Sci 14: 369-376.

Tarkan AS, Copp GH, Top N, et al. 2012. Are introduced gibel carp Carassius gibelio in Turkey more invasive in artificial than in natural waters? Fish Manag Ecol 19: 178-187.

Tereshchenko VG, Khrystenko DS, Kotovska GO, Tereshchenko LI. 2016. The specific rate of the population dynamics of the blackstriped pipefish Sygnathus nigrolineatus Eichwald, 1831 in the Kremenchug and Dneprodzerzhinsk Reservoirs at different phases of the naturalization of the species. Inland Water Biol 9: $79-86$.

Trewavas E. 1983. Tilapiine Fishes of the Genera Sarotherodon, Oreochromis and Danakilia, British Museum (Natural History).

Turan D, Japoshvili B, Aksu İ, Bektaş Y. 2016. Description of two new species of the genus Gobio (Teleostei: Cyprinidae) from the Black Sea coast of Turkey. Zool Middle East 62: 112-124.

Vasil'eva ED. 2007. Gobies of the genus Rhinogobius (Gobiidae) from Primor'e and water bodies of Central Asia and Kazakhstan: I. Morphological characteristic and taxonomic status. J Ichthyol 47: 691-700.

Vetemaa M, Eschbaum R, Albert A, Saat T. 2005. Distribution, sex ratio and growth of Carassius gibelio (Bloch) in coastal and inland waters of Estonia (north-eastern Baltic Sea). J Appl Ichthyol 287-291. 
T. Kuljanishvili et al.: Knowl. Manag. Aquat. Ecosyst. 2021, 422, 32

Vidal O, García-Berthou E, Tedesco PA, García-Marín JL. 2010. Origin and genetic diversity of mosquitofish (Gambusia holbrooki) introduced to Europe. Biol Invas 12: 841-851.

Vitousek P, D'Antonio C, Loope L, Westbrooks R. 1996. Biological invasions as global environmental change. Am Sci 84: 468-478.

Wouters J, Janson S, Lusková V, Olsén KH. 2012. Molecular identification of hybrids of the invasive gibel carp Carassius auratus gibelio and crucian carp Carassius carassius in Swedish waters. J Fish Biol 80: 2595-2604.

Yusifov EF, Alekperov IK, Ibrahimov SR, Aliyev AR, Guliyev GN, Mustafayev NJ. 2017. About the biological diversity of inland water ecosystems in Azerbaijan. Proc ANAS 72: 74-91.
Zambrano L, Martínez-Meyer E, Menezes N, Peterson AT. 2006. Invasive potential of common carp (Cyprinus carpio) and Nile tilapia (Oreochromis niloticus) in American freshwater systems. Can J Fish Aquat Sci 63: 1903-1910.

Zareian H, Zamanian Nejad R, Vatandoust S. 2015. Hemiculter leucisculus (Basilewsky, 1855) and Alburnus caeruleus Heckel, 1843: new data on their distributions in Iran. Caspian J Environ Sci 13: $11-20$.

Žitňan R. 1974. Acclimatization of fish in the Carpathian region of Czechoslovakia and the role of helminths in this process. Ichthyologia 6: 143-155.

Cite this article as: Kuljanishvili T, Mumladze L, Japoshvili B, Mustafayev N, Ibrahimov S, Patoka J, Pipoyan S, Kalous L. 2021. The first unified inventory of non-native fishes of the South Caucasian countries, Armenia, Azerbaijan, and Georgia. Knowl. Manag. Aquat. Ecosyst., 422,32 . 